\title{
The Nature Biotechnology 1998 New Year quiz
}

In a month named after a Roman god who faced both forward and backward, we take a sideways look at the international biotechnology scene. As in real life, teamwork and informed guesses will, in most cases, be good enough to see you through. Answers on p. 99.

1. "Disappeared" in 1997. But under what circumstances?

(a) Alex Zaffaroni, financier and founder of ALZA and Affymax, and the man who introduced Robert Maxwell and Bill Gates to biotechnology;

(b) Dutch plant biotechnology company, Mogen International, in June;

(c) Seragen, in September, and its chairman, James Howell, in January;

(d) $\sim 50$ million worth of shares belonging to Biogen's CEO Jim Vincent, in February;

(e) The National Center for Human Genome Research, in January;

(f) Savant Biotechnology and its healthcare interests, in September.

\section{Every time I open my mouth, some} fool speaks.

(a) What, in November, was "like putting two steaming cups of coffee together to make one boiling vat of "burn-your-thighs" coffee"?

(b) Who, according to the Denver Post, was "going to go into the shoe business" if his company's oligonucleotide synthesis method did not make a big impact? (c) Which lawyer allegedly said in a revealing Associated Press story postDolly that his organization was "adamantly opposed to human clothing." (d) What, on November 21, was both "The first comprehensive modernization of the FDA in more than 30 years" and "The worst attack on the FDA's ability to protect consumers and patients in 91 years"?

\section{Think of a name, any name. What's} common in:

(a) gen, _s, _mira, _com;

(b) zyme, Immuno, Kabi, Am

(c) agene, Phyto_, Neo

acopeia;

(d) In , Pro, 1, Bio ;

(e)_uenom, _uana, $\mathrm{Hy}$, _ wright;

(f) gen, _probe, se, _ pharm;

(g) Biomedica, _ GlycoScience, Molecular, _ Assymmetry;

(h) _ypte, gene, _zyme, _tag?

4. Mission mishmash. Some buffoon at the PR agency has mixed up all the company mission statement. Can you realign the corporate strategic directions?

(a) Acacia Biosciences develops and markets complete systems for the detection of rare events - cells and bacteria-for the agri-food industry and the medical community (1)

(b) ArQule is a functional genomics company developing proprietary technologies for enhancing the speed and efficiency of drug discovery and development (2)

(c) Biocom is a genomics pharmaceutical company focused on the identification of novel drug targets through the large scale definition of gene function (3)

(d) BioStratum is a leading chemistry company in accelerated drug discovery using its high throughput lead generation and lead optimization technologies (4)

(e) Chiroscience is a pharmacogenomics company focused today on developing metrics and therapeutics for diseases caused or affected by abnormalities in the mitochondrial genome (5)

(f) Geron is a privately held biotechnology company developing a new class of proprietary therapeutics based on recent scientific advances in basal lamina technology (6)

(g) Lexicon Genetics is an emerging biopharmaceutical group specializing in the discovery and development of new small molecule drugs originally derived from naturally occurring microorganisms, such as fungi and bacteria, and from plants (7) (h) MitoKor is an emerging pharmaceutical company which uses its diverse technology platform to discover and develop novel medicines for improved healthcare (8)

(i) Signal Pharmaceuticals is an integrated target and drug discovery company focused on identifying new classes of small molecule drugs that regulate genes and the productions of disease-causing proteins (9)

(j) Xenova is exclusively focused on discovering and developing therapeutics and diagnostic products based upon common biological mechanisms underlying cancer and other age-related diseases (10)

5. Getting it together. Name the academic-industry joint ventures:

(a) The Royal College of Surgeons in Dublin with Genset;

(b) The Whitehead Research Institute with Millennium Pharmaceuticals, Affymetrix, and Bristol Myers Squibb;

(c) The Memorial Sloane-Kettering Cancer Center with Sequana Therapeutics;

(d) The Cold Spring Harbor Laboratory with Oncogene Science and HoffmannLa Roche.

6. Odd ones out. Which is the deviant?

(a) Escherichia coli, Streptococcus pyogenes; Bacillus subtilis, Helicobacter pylori, Archaeoglobus fulgidus;

(b) Polly, Tracy, Gene,

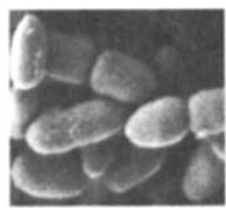

Rosie, Herman, Astrid;

(c) Protropin, Geref, Saizen, Norditropin, Humatrope, Posilac;

(d) Avonex, Intron A; Roferon, Infergen; (e) Yieldgard, Liberty Link, Bollgard, New Leaf, Roundup Ready soya; (f) Millennium Biologicals, Millennium

Predictive Medicine, Millennium Pharmaceuticals, Millenium Biologix.
7. Forever friends. How did shining environmental campaigners

Greenpeace help bad boy global agroimperialists Monsanto give biotechnology the credit it was due in June 1997?

\section{Classical pretensions. Which com-} pany's name:

(a) was a pagan goddess personifying the French river Seine. In Roman times, dedications were made at her temple to ensure good health;

(b) is a Greek word meaning the presage of good luck or anticipation of future discoveries;

(c) comes from the latin for "eagle".

\section{Offspring. Name:}

(a) SmithKline Beecham's scion focusing on point-of-care diagnostics;

(b) W.R. Grace's spin-out in gene delivery and in vivo gene therapy;

(c) The fruit of Novartis' loin developing protein kinase inhibitors;

(d) American Home Products' explant specializing in drug delivery for periodontal disease;

(e) SmithKline Beecham's "lost project" developer. 